\title{
Efektivitas Pendekatan Struktural Genetik Dalam Pembelajaran Mengkreasi Puisi Pada Siswa Kelas IV SD Inpres Kecamatan Tamalanrea Kota Makassar
}

\section{The Effect of Storytelling Method Assisted with LCD Projectors on Listening and Speaking Skills of Students in SDN 64 Malaka Maros Regency}

\author{
Lilik Lestari ${ }^{1}$, Asdar $^{2}$, A. Hamsiah ${ }^{2}$ \\ ${ }^{1}$ Dinas Pendidikan Kota Makasssar, Sulawesi Selatan \\ ${ }^{2}$ Program Studi Studi Pendidikan Dasar, Program Pascasarjana, Universitas Bosowa \\ E-mail: liliklestari808@gmail.com
}

Diterima: 10 Januari 2021/Disetujui 09 Juni 2021

\begin{abstract}
Abstrak. Tujuan penelitian ini adalah untuk mengetahui keefektifan pendekatan struktural genetik dalam pembelajaran puisi pada siswa kelas IV SD Inpres Kecamatan Tamalanrea Kota Makassar. Subyek dalam penelitian ini dikelompokkan atas dua kelompok, yaitu siswa kelas IV A SD Inpres Tamalanrea 3 sebagai kelas kontrol dan siswa IV B SD Inpres Tamalanrea 4 sebagai kelas eksperimen. Penelitian ini dibagi ke dalam dua kelas, yaitu kelas eksperimen dan kelas kontrol. Sebelum diberikan perlakuan kepada kelas eksperimen, maka kedua kelas itu diberikan tes awal (pree test). Setelah perlakuan itu diberikan kepada kelas eksperimen, maka kedua kelas tersebut diberikan tes kembali (post-test) untuk mengetahui perbedaan hasil dari kedua kelas itu. Teknik pengumpulan data mengunakan teknik observasi, tes awal, dan tes akhir. Data dianalisis secara deskriptif dan analisis inferensial. Hasil penelitian ini menunjukkaqn bahwa: nilai rata-rata post test kelas eksperimen lebih besar dari pada nilai rata-rata kelas kontrol yaitu 75,19>65,62. Ini berarti bahwa pembelajaran dengan menggunakan pendekatan struktural genetik pada lebih efektif dibandingkan dengan siswa yang tidak menggunakan pendekatan structural genetic.
\end{abstract}

Kata Kunci: Pendekatan Structural Genetic, Pembelajaran, Mengkreasikan Puisi

\begin{abstract}
The purpose of this study was to determine the effectiveness of genetic structural approach in teaching poetry for fourth grade students of SD Inpres, Tamalanrea District, Makassar City. The subjects in this study were grouped into two groups, namely grade IV A SD Inpres Tamalanrea 3 as the control class and students IV B SD Inpres Tamalanrea 4 as the experimental class. This study was divided into two classes, namely the experimental class and the control class. Before given treatment to the experimental class, the two classes were given a pre-test. After the treatment was given to the experimental class, the two classes were given a post-test to determine the difference in the results of the two classes. Data collection techniques used observation techniques, pre-test, and post-test. Data were analyzed descriptively and inferential analysis. The results of this study indicate that: the post-test mean score of the experimental class is greater than the control class average score, which is 75.19>65.62. This means that students learning using genetic structural approach is more effective than those who do not use genetic structural approach.
\end{abstract}

Keywords: Genetic Structural Approach, Learning, Creating Poetry

\section{Pendahuluan}

Era globalisasi merupakan suatu era yang harus dihadapi oleh setiap bangsa dan negara yang ada di dunia Bahasa adalah hasil budaya yang hidup, yang berkembang dan yang harus dipelajari oleh setiap manusia. Bahasa menurut KBBI Depdiknas (2008) adalah "sistem lambang bunyi berartikulasi yang bersifat sewenang-wenang dan konvensional yang dipakai sebagai alat komunikasi untuk melahirkan perasaan dan pikiran”. Bahasa merupakan suatu budaya yang berharga dari masa ke masa berikutnya. Pengembangan bahasa dapat dilalui dengan jalur pendidikan formal maupun nonformal (Baena, 2010). Pengembangan pendidikan formal dimulai dari sekolah dasar, sekolah dasar merupakan jenjang pertama, seyogyanya dapat membentuk landasan pondasi yang kuat untuk tingkatan pendidikan selanjutnya hingga masa depannya, sehingga sekolah harus membekali lulusannya dengan kemampuan dan keterampilan dasar yang memadai di antaranya keterampilan berbahasa.

Dalam UU RI nomor 14 Tahun 2005 tentang guru dan dosen bahwa prinsip profesionalitas mencakup bidang pekerjaan khusus yang di dalamnya termasuk seorang guru atau dosen harus memiliki bakat, minat, panggilan jiwa, dan idealism (Faruk, 1988). Jelas bahwa tatanan kepemilikan karakter yang kuat dari seorang guru dan dosen di tuntut memiliki komitmen demi meningkatkan mutu pendidikan, keimanan dan akhlak mulia. Sebagai seorang guru yang mendidik dan mengajar, selayaknya memiliki kepribadian yang patut diteladani, yaitu kompetensi pedagogik, kompetensi kepribadian, kompetensi sosial, dan kompetensi profesional. Pembelajaran bahasa Indonesia di sekolah dasar pada hakikatnya merupakan salah satu sarana mengupayakan pengembangan dan pembinaan bahasa Indonesia secara terarah. Maka dari itu, melalui proses 
pengajaran bahasa diharapkan siswa mempunyai kemampuan yang memadai untuk dapat menggunakan bahasa Indonesia dengan baik dan benar. Menurut Nurgiyanto (2000) Penguasaan bahasa Indonesia yang baik dapat diketahui dari standar kompetensi membaca, menulis, berbicara, dan mendengarkan (menyimak).

Pembelajaran Bahasa Indonesia pengembangannya melalui pendidikan formal, yang berfungsi sebagai pusat budaya dan pembudayaan baca tulis (Slamet, 2007). Kemampuan proses strategisnya adalah keterampilan berbahasa dengan kemampuan bahasa yang dimiliki, siswa mampu menimba berbagai pengetahuan, mengmembaca seni, serta mengembangkan diri secara berkelanjutan (Samsu, 2011). Selanjutnya lebih jauh lagi siswa akan terjun menjadi makhluk sosial, membentuk pribadi sebagai warga Negara, dan proses perkembangan masyarakat untuk masa depan yang ditandai dengan kemajuan teknologi, kemampuan membaca, menulis perlu dikembangkan secara sungguh-sungguh. Maka jelas pembelajaran bahasa Indonesia yang dalam hal ini dimulai dari sekolah dasar perlu dilaksanakan dengan benar. Zulela (2012, 4) menyatakan bahwa mempelajari bahasa untuk dipergunakan dalam kehidupan sehari-hari merupakan kebutuhan utama manusia, sebab dengan bahasa, manusia dapat berpikir. Pembelajaran membaca puisi dapat membantu siswa dalam mengembangkan kualitas kepribadian, antara lain ketekunan, kepandaian, pengimajinasian, dan penciptaan. Melalui kegiatan membaca puisi, siswa selalu dipertemukan dengan berbagai pengalaman terutama pengalaman batin. Misalnya pengalaman menginterprestasikan karya sastra, pengalaman mengikuti dan menganalisis puisi, sampai pada bagaimana siswa mengalami proses kreatif menciptakan puisi. Faktor guru sangat berpengaruh terhadap kelangsungan proses belajar mengajar (Jainuddin, 2019). Keberhasilan proses pembelajaran tidak dapat lepas dari peran guru. Tetapi pada fakta di lapangan masih banyak guru yang kurang memahami pendekatan yang tepat dalam pengajaran sastra khususnya dalam puisi. Dan pada akhirnya pembelajaran membaca puisi di sekolah-sekolah kurang efektif, ini berimbas pula pada nilai-nilai moral dan kemanusiaan siswa serta merosotnya kualitas kepribadian siswa yang dapat mengakibatkan banyak generasi muda siswa-siswa yang bersikap kurang sopan dan hormat kepada orang tua bahkan guru, hal ini dapat dicegah dengan cara mengasah perasaan siswa melalui pembelajaran membaca puisi.

Pada kenyataannya, pembelajaran sastra khususnya puisi di sekolah dasar belum memenuhi harapan. Banyak faktor yang menyebabkan pembelajaran sastra belum berlangsung seperti yang diharapkan. Selain akibat lemahnya kemampuan guru juga dikarenakan kurangnya minat anak dalam belajar. Masalah ini muncul karena dalam proses belajar mengajar guru jarang menghadirkan karya sastra itu sendiri (Jainuddin, 2020). Guru mengandalkan memori dan tidak memusatkan perhatian pada pengembangan kreativitas serta keterlibatan siswa dalam pembelajaran puisi. Sehubungan dengan hal tersebut hadirnya sarana sebagai dukungan sangat diharapkan. Sarana yang dimaksud adalah buku-buku yang berhubungan dengan sastra, majalah, dan surat kabar yang tersedia di perpustakaan.

Bahasa Indonesia khususnya membaca puisi perlu diajarkan melalui metode pembelajaran yang dinamis serta pendekatan pembelajaran yang mampu merangsang kreativitas siswa sehinggah tumbuh dan berkembang serta tidak bosan melainkan dapat menyerap setiap materi yang diajarkan. Pembelajaran merupakan suatu proses yang sangat kompleks, dimana peran guru tidak hanya sebagai penyampaian informasi kepada siswa tetapi bagaimana memberi rangsangan, bimbingan, pengarahan dan dorongan kepada siswa agar terjadi proses belajar (Darmawan: 2021). Pembelajaran yang baik melibatkan aspek-aspek yang berhubungan dengan apa yang sebenarnya dipelajari oleh siswa melalui partisipasinya.

Berdasarkan hasil obesrvasi awal yang dilakukan oleh peneliti terhadap siswa di sekolah yang dijadikan sampel penelitian belum mencapai standar kompetensi dengan standar KKM minimal 70. Pembelajaran puisi memang sudah diterapkan oleh guru, namun minat dan keinginan siswa dalam membaca puisi belum mencapai target yang diinginkan dan guru mengajar hanya untuk menjalankan tugas sebagai pengajar dan tidak memperhatikan siswa sebagai subjek dalam pembelajaran, pendekatan yang digunakan guru juga masih secara konvensional sehingga materi pelajaran bahasa Indonesia yang diajarkan tidak dipahami secara komprehensif dan mengakibatkan hasil akhir pun tidak memuaskan. Guru belum mencoba menerapkan metode dan pendekatan lain yang memungkinkan dapat mencapai target sesuai dengan standar kompetensi yang telah dijabarkan. Perubahan dalam pembelajaran Bahasa Indonesia sangat berhubungan erat dengan masalah pendekatan dan metodenya karena keduanya merupakan bagian yang penting dalam merumuskan pembelajaran yang menyangkut dengan siswa dan kemampuannya.

Pembelajaran membaca puisi pada siswa SD Inpres Tamalanrea 3 dan SD Inpres Tamalanrea 4 Makassar khususnya siswa kelas IV selama ini berjalan kurang efektif yang berakibat kemampuan siswa membaca puisi perlu ditingkatkan. Salah satu alternatif meningkatkan pemahaman puisi siswa adalah dengan pendekatan struktural genetik.

Analisis struktur merupakan salah satu hal penting dalam pembelajaran membaca sastra. Dikatakan penting karena dengan adanya analisis struktur dari sebuah karya sastra puisi akan memberikan pemahaman yang lebih mendalam bagi siswa mengenal makna isi sebuah puisi tersebut. Puisi yang merupakan gambaran kehidupan maka siswa dapat mengambil hikmah dan belajar tentang hidup yang sebenarnya. Pendekatan ini adalah pendekatan dalam pembelajaran sastra yang mengkaji puisi (yang disesuaikan dengan jenjang tingkatan pendidikan) dengan menelaah struktur fisik (diksi, tipografi, kata konkret, rima dan majas), struktur batin(tema, rasa, amanat,dan imaji), dan faktor genetik berupa latar belakang sosial budaya penyair,asal usul karya sastra yaitu pengarang dan kenyataan sejarah yang turut mengkondisikan saat karya itu diciptakan. Masing-masing struktur disesuaikan dengan batas kemampuan siswa di tingkat sekolah dasar dan disesuaikan dengan kurikulum Bahasa Indonesia yang berlaku saat ini. Kembali pada pendekatan pembelajaran, guru harus mempu menyiasati dan mendorong siswa dalam mengembangkan pengetahuan yang dimiliki. Penelitian tentang puisi sudah banyak dilakukan oleh penelitipeneliti sebelumnya baik sastra maupun pengajarannya, tetapi mereka hanya mengukur kemampuan siswa dalam menciptakan puisi. Akan tetapi tidak membicarakan masalah pendekatan dalam pembelajaran yang memberikan pengajaran yang tuntas dan menyeluruh dalam suatu karya puisi. Asumsi inilah dan masalah pengajaran bahasa indonesia yang klasik di SD Inpres Tamalanrea3 dan SD Inpres Tamalanrea 4 Makassar yang menjadi alasan peneliti memilih judul Pengaruh pendekatan Struktural Genetik dalam pembelajaran mengkreasi Puisi pada siswa Kelas IV SD Inpres Tamalanrea Makassar. 
Peneliti melakukan penelitian dengan harapan dapat memperbaiki strategi pembelajaran bahasa Indonesia khususnya sastra, yang dapat memberikan solusi terhadap pembelajaran membaca puisi yang dianggap belum optimal.

\section{Metode Penelitian}

Jenis penelitian ini adalah penelitian eksperimen, Pendekatan penelitian yang digunakan adalah pendekatan kuantitatif, yang didesain dengan menggunakan desain penelitian pretestt-postteskontrol group design. Penelitian ini dilaksanakan di SD Inpres Tamalanrea 3 dan SD Inpres Tamalanrea 4 Kecamatan Tamalanrea Kota Makassar Kelas IV pada bulan Oktober Tahun 2020 semester ganjil tahun pelajaran 2020-2021 atau mengikuti jadwal sekolah. Arikunto (1997) mengatakan bahwa: "Apabila subjeknya kurang dari 100, lebih baik diambil semua sehingga penelitiannya merupakan penelitian populasi. Apabila jumlah subyeknya besar dapat diambil antara 10-15\% atau 20-25\% atau lebih, bergantung setidak-tidaknya pada kemampuan peneliti dilihat dari waktu, tenaga, dan dana, sempit luasnya pengamatan dari setiap subjek besar kecilnya resiko yang ditanggung oleh peneliti." Sampel dalam penelitian ini dikelompokkan atas dua kelompok, yaitu siswa kelas IV yang terdiri dari kelas IV A SD Inpres Tamalanrea 3 sebanyak 24 siswa sebagai kelompok/kelas kontrol dan IV B SD Inpres Tamalanrea 4 sebanyak 26 siswa sebagai kelompok/kelas eksperimen. Pemilihan penentuan kelas eksperimen dan kontrol dilakukan secara random. Data yang diperoleh dalam penelitian ini semuanya diolah dan dianalisis dengan menggunakan teknik statistik yaitu teknik analisis hasil penelitian dengan menggunakan statistik deskriptif dan statistik inferensial.

\section{Hasil dan Pembahasan}

Proses hasil pembelajaran siswa dinilai berdasarkan tiga aspek dari pendekatan struktural genetik yaitu struktur fisik, struktur batin dan faktor genetik, hal ini sesuai dengan uraian Faruk (1988) teori struktural genetik adalah suatu disiplin yang memandang karya sastra sebagai suatu struktur yang terdiri atas beberapa unsur yang saling berkaitan antara satu dengan yang lainnya. Hasil analisis data menunjukkan bahwa tidak terdapat perbedaan berarti antara kemampuan siswa dalam memahami puisi sebelum pemberian perlakuan. Hal ini ditunjukkan dengan rata-rata kemampuan siswa dalam memahami puisi yang relatif sama. Hasil ini menurut penelitian sangat wajar, mengingat pendekatan yang digunakan guru dalam pembelajaran puisi sama, yakni pendekatan konvensional.

Pendekatan struktural genetik yang dilakukan dengan aktivitas pembelajaran puisi siswa kelas IV SD Inpres Tamalanrea 4 Makassar, bersifat procedural dalam arti penerapan metode pembelajaran puisi dilaksanakan dengan melalui langkahlangkah yang teratur dan secara bertahap, dimulai dari penyusunan RPP, pelaksanaan proses pembelajaran, dan penilaian hasil belajar. Pendekatan struktural genetik yang dieksperimenkan adalah metode kerja Goldmann, dapat dirumuskan sebagai berikut: (1) penelitian dilakukan bertahap satu puisi yang dilihat sebagai satu kesatuan. (2) puisi yang dianalisis hanya puisi yang mempunyai nilai sastra yang biasanya mengandung keterangan antara kesatuan ke dalam suatu keseluruhan yang padat.

Data-data yang diperoleh dalam penelitian ini dianalisis secara deskriptif dan analisis inferensial. Dari analisis deskriptif terlihat bahwa pada tes terakhir (post test) siswa kelas IV SD Inpres Tamalanrea 4 Makassar (kelas eksperimen) keefektifan pemahaman puisi lebih baik daripada ) siswa kelas IV SD Inpres Tamalanrea 3 Makassar (kelas kontrol) yang ditunjukan dengan rata-rata perolehan hasil belajar siswa pada kelas eksperimen adalah 75,19 sedangkan kelas kontrol adalah 65,62 dengan ketuntasan secara klasikal pada kelas eksperimen adalah 79,62\% sedangkan pada kelas kontrol adalah $50 \%$. Analisis deskriptif untuk kelas kontrol menunjukkan bahwa keefektifan hasil belajar siswa kurang meningkat. Dari hasil pengkategorian terlihat bahwa pada tes awal tidak ada siswa yang berada pada kategori sangat baik dan 15 orang atau $62,5 \%$ berada pada kategori kurang sedangkan pada tes akhir, hanya 1 orang siswa atau $4,16 \%$ yang berada pada kategori sangat baik dan 5 orang siswa atau 20,83\% berada pada kategori kurang. Peningkatan ini cukup rendah dibandingkan dengan kelas eksperimen. Dimana pada tes awal kelas eksperimen tidak ada siswa yang berada pada kategori sangat baik dan 13 orang atau $50 \%$ berada pada kategori kurang, sedangkan pada tes akhir terdapat 9 orang atau 34,61\% yang berada pada kategori sangat baik dan 1 orang siswa atau 3,84\% yang berada pada kategori kurang.

Secara analisis deskriptif, jika dibandingkan antara kelas eksperimen dan kelas kontrol, keefektifan pemahaman puisi siswa dengan penggunaan pendekatan struktural genetik lebih meningkat dibandingkan dengan kelas kontrol yang tidak menggunakan pendekatan structural genetic (pendekatan konvensional). Dari analisis deskriptif terlihat bahwa kelas eksperimen, terdapat peningkatan hasil belajar yang cukup tajam. Selanjutnya setelah pelaksanaan perlakuan pada siswa kelas IV SD Inpres Tamalanrea 3 Makassar (kelas kontrol) yang tidak menggunakan pendekatan structural genetik (pendekatan konvensional) dan pelaksanaan perlakuan pada siswa kelas IV SD Inpres Tamalanrea 4 Makssar (kelas eksperimen) yang menggunakan pendekatan struktural genetik, maka pemahaman puisi siswa dengan menggunakan pendekatan struktural genetik lebih baik dibandingkan pemahaman puisi dengan yang tidak diberi pendekatan structural genetik (pendekatan konvensional pada kelas kontrol).

Untuk mengetahui ada perbedaan yang berarti antara skor yang diperoleh kelas eksperimen dan kelas kontrol dilakukan uji $\mathbf{t}$ dalam analisis inferensial. Syarat untuk melakukan uji $\mathbf{t}$ adalah data-data yang diperoleh harus berdistribusi normal dan homogen. Data-data yang diperoleh masing-masing dari tes awal dan tes akhir pada kelas eksperimen dan kelas kontrol. Pengujian hipotesis dengan uji t karena semua data berdistribusi normal, serta varians kedua kelas homogen. Uji ini dimaksudkan untuk mengetahui ada perbedaan antara hasil pembelajaran puisi dengan pendekatan struktural genetik dengan yang tidak menggunakan pendekatan structural genetic (pendekatan konvensional) sehingga dapat diketahui bahwa pendekatan struktural genetik efektif atau tidak efektif dilakukan dalam pembelajaran puisi untuk meningkatkan pemahaman puisi siswa. Hasil uji t menunjukkan adanya peningkatan yang signifikan pada hasil pembelajaran puisi pada kelas yang telah 
diberi pembelajaran puisi dengan pendekatan sturktural genetik sebagai kelas eksperimen dengan pendekatan konvensional sebagai kelas kontrol. Nilai rata-rata post test kelas eksperimen lebih besar dari pada nilai rata-rata kelas kontrol yaitu 75,19 > 65,62. Hasil uji hipotesis menunjukan bahwa Ho ditolak dan Hi diterima dengan nilai signifikan $\mathrm{P}($ Sig. 2 -tailed $)=0,002<\alpha$ 0.05. Ini berarti bahwa pembelajaran dengan menggunakan pendekatan struktural genetik pada kelas eksperimen lebih efektif dibandingkan dengan siswa yang tidak menggunakan pendekatan structural genetic (pendekatan konvensional).

Hasil penelitian ini sejalan dengan pendapat Waluyo (1995) bahwa pembahasan puisi Indonesia dapat lebih terarah pada sasara yang tepat dengan menggunakan pendekatan struktural genetik. Artinya, dengan pendekatan strruktural genetik ini pembahasan puisi dapat dilakukan secara utuh dan menyeluruh sebagai suatu totalitas sehingga siswa lebih mudah memahami makna puisi yang dibacanya. Berdasarkan temuan ini, maka seorang guru sudah sepatutnya merencanakan dan melaksanakan pembelajaran puisi dengan mengkaji dan menganalisis puisi berdasarkan struktur fisik, struktur batin dan faktor genetik puisi. Pembelajaran puisi dengan menggunakan pendekatan struktural genetik dapat memudahkan siswa memahami puisi secara utuh dan menyeluruh dan telah terbukti dapat meningkatkan kemampuan siswa dalam memahami puisi.

\section{Kesimpulan dan Saran}

Hasil penelitian dapat disimpulkan bahwa terdapat perbedaan yang signifikan dalam pemahaman puisi siswa kelas IV SD Inpres Tamalanrea 4 Makassar dengan pemahaman puisi siswa kelas IV SD Inpres Tamalanrea 3 Makassar antara pembelajaran dengan menggunakan pendekatan struktural genetik dengan yang tidak menggunakan pendekatan struktural genetik. Pemahaman puisi pada siswa yang diajar dengan menggunakan pendekatan struktural genetik dengan siswa yang diajar dengan menggunakan pendekataran konvensional, secara keseluruhan terdapat perbedaan yang signifikan. Tingkat keefektifan pembelajaran dengan menggunakan pendekatan struktural genetik pada kelas eksperimen lebih efektif dibandingkan dengan siswa yang tidak menggunakan pendekatan structural genetic (pendekatan konvensional). Pendekatan struktural genetik efektif dalam meningkatkan pemahaman puisi siswa kelas IV SD Inpres Tamalanrea 4 Makassar.

\section{Daftar Pustaka}

Arikunto, Suharsimi. 1993. Manajemen Pengajaran Secara Manusiawi. Jakarta: Rineka Cipta.

Baena. 2010. Pemahaman Puisi dengan Pendekatan Struktural Genetik Mahasiswa Universitas Muhammadiyah Makassar. Tesis. Makassar: UNISMUH

Darmawan, F. A., \& Jainuddin, J. (2021). Augmented Reality-based Mathematics Worksheet for Online Learning During Covid-19 Pandemic. Indonesian Journal of Educational Studies, 23(2), 81-90.

Dipalaya, T. (2020). Field Experience Practices Based Lesson Study (Ls) To Improve Students Communication Skills And Collaboration. Klasikal: Journal Of Education, Language Teaching And Science, 2(1), 48-62.

Faruk. 1988. Epistemologi Sastra dan Strukturalisme Genetik. Yogyakarta: Lukman Offset.

Jainuddin, J. (2019). Peningkatan Hasil Belajar Matematika Melalui Latihan Menyelesaikan Soal Secara Sistematis Pada Siswa Kelas XI. IPA1 SMA NEGERI 2 Sungguminasa. Klasikal: Journal Of Education, Language Teaching And Science, 1(3), 44-52.

Jainuddin, J., \& Sirajuddin, S. (2020). Pengaruh Minat dan Kedisiplinan Siswa dengan Gaya Kognitif Field Indefendent terhadap Hasil Belajar Matematika Siswa SMK Farmasi Yamasi Makassar. Delta-Pi: Jurnal Matematika dan Pendidikan Matematika, 9(2).

KBBI, 2018. Kamus Besar Bahasa Indonesia (KBBI). [Online, diakses tanggal 8 mei 2018]

Nurgiayantoro, Burhan. 2000. Penelitian dalam Pengajaran Bahasa dan Sastra Indonesia Edisi Ketiga. Yogyakarta: BPFE

Slamet, St. Y. 2007. Dasar-Dasar Keterampilan Berbahasa Indonesia. Surakarta: Universitas Sebelas Maret Press.

Sumadyo, Samsu. 2011. Strategi dan Teknik Pembelajaran Membaca. Yogyakarta: Graha Ilmu.

Zulela. 2012. Pembelajaran Bahasa Indonesia Membaca Sastra di Sekolah Dasar. Bandung: Remaja Rosdakarya. 